\title{
Frig Tipi Fibulalarda Tanrıça Sembolizmi Üzerine Bazı Düşünceler
}

\section{Emre Erdan ${ }^{*}$}

Öz

Anadolu Demir Çağı'nın en önemli uygarlıkları arasında sayılan Frigler, Matar-Kybele Kültü’ne büyük saygı duymuşlardır. Söz konusu toplum için neredeyse doğanın bizzat kendisi konumunda yer aldığı, çeşitli kültür ögeleri aracılığıyla doğrulanan inanç sisteminin başlıca ögesi olan tanrıça, Frigler tarafindan farkı biçimlerde yansıtılmıştır. Tanrıçanın, Frig sanat eserlerinde doğrudan betimlendiği heykel ve yüksek kabartma gibi eserler olabildiği gibi, aynı zamanda idol biçimli temsili ögeler çerçevesinde değerlendirildiği de bilinmektedir. Çalışmamız, sembolizm kapsamında değerlendirebileceğimiz ve farklı Frig ögelerinden tanıdığımız Matar-Kybele idollerinin temsili olarak Frig fibulalarının iğne tutamak plakalarında yansıtıldığına inandığımız görünümünü açıklamaya yöneliktir. Çok sayıda alt grup kapsamında değerlendirilen Frig fibulalarının en erken örnekleri arasında sayılan Tip XII-7A fibulaları ile başlatılan temsili tanrıça görünümü zamanla standart ve karakteristik bir özelliğe dönüşmüştür.

\section{Anahtar Kelimeler}

Frig • Fibulalar • Demir Çağ • Matar-Kybele • Sembolizm

\section{Some Thoughts About the Goddess Symbolism on Phrygian Type Fibulae}

\begin{abstract}
The Phrygians, considered among the most important civilizations of the Anatolian Iron Age, had great respect for MatarKybele. The goddess, who is the key element of the belief system that is clearly understood today, is reflected in different ways by the Phrygians. It is also known that the goddess not only was directly reflected in masterpieces such as sculpture and high relief by the Phrygians, but also was evaluated in the form of idol-shaped representations. This study is intended to explain that the Phrygian fibulae are reflected in catch plates as a representation of Matar-Kybele idols that we can evaluate within the scope of symbolism and which we recognize from different Phrygian artefacts. Starting with the Type XII-7A, which are one of the earliest examples of Phrygian fibulae, the goddess appearance has evolved into a standard and characteristic feature over time.
\end{abstract}

\section{Keywords}

Phrygian • Fibulae $\bullet$ Iron Age $\bullet$ Matar-Cybele $\bullet$ Symbolism

* Sorumlu Yazar: Emre Erdan (Dr. Öğr. Üyesi), Adnan Menderes Üniversitesi, Fen-Edebiyat Fakültesi, Arkeoloji Bölümü, Aydın, Türkiye. Eposta: erdanemre@gmail.com

Atff: ERDAN, Emre, "Frig Tipi Fibulalarda Tanrıça Sembolizmi Üzerine Bazı Düşünceler", Art-Sanat, 11(Ocak 2019), s. 163-185. https://doi.org/10.26650/artsanat.2019.11.0007 


\section{Giriş}

Giysileri daha sağlam ve güvenli bir şekilde tutturmak amacıyla üretimine başlanmış ve eskinin çengelli iğnesi olarak anabileceğimiz fibulaların ilk olarak nerede ve ne zaman üretilmeye başlandıkları bilinmemektedir. Muscarella tarafından, bir çeşit kimlik kartına benzetilen Frig tipi fibulalar, sergiledikleri farklı özellikler itibariyle hem Anadolu hem de çevre kültürlerde karşılaşılan tiplerden ayrılmaktadır ${ }^{1}$. Bu çalışma, Frig tipi fibulaların karakteristik özellikleri arasında sayılan ve çoğunlukla "boynuz" ya da "pençe" olarak tanımlanan iğne tutamak plakalarını, hem öncül kültürlerin, hem de Friglerin diğer yapıtlarından tanınan tanrıça ikonografisinin özellikleriyle değerlendirmeye yöneliktir. Çalışmamızda, Frig tipi fibulaların iğne tutamak plakasında yer alan ve yukarıda andığımız farklı tanımlarla bir arada değerlendirilen biçem özelliği, tanrıçanın omega sembolü olarak da adlandırılan ve öncü örnekleri Yakındoğu'nun güçlü tanrıçaları olan Ninhursag ve Hathor'a uzanan, ucu kıvrık saç tipi temel alınarak değerlendirilmiştir.

\section{Frig Tipi Fibulalar}

Frig bronz işçiliğinin en özgün buluntularının sayıca en fazla grubunu fibulalar oluşturmaktadır. Frig başkenti Gordion'da özellikle tümülüslerde oldukça fazla sayıda ele geçen fibulaların, diğer başlıca Frig merkezlerinden ele geçen örnekleri de bilinmektedir. Genellikle bronz, nadir olarak altın, gümüş ve elektron gibi değerli madenler kullanılarak üretildiği bilinen fibulaların tarihlendirilmesi konusunda farklı görüşler bulunmaktadır².

Danimarkalı araştırmacı ve akademisyen Blinkenberg tarafından kapsamlı olarak incelenen fibulalar çok sayıda alt gruba ayrılmıştır. Anadolu ve Frig örneklerini kapsayan sayıca en fazla olan XII. gruptur ve Anadolu'da Gordion başta olmak üzere, Ankara, Alişar, Bayraklı, Boğazköy, Ephesos, Eskişehir, İvriz, Kerkenes, Midas Kenti, Larisa, Manisa, Pazarlı, Sardis ve Troia gibi merkezler aracılığıyla bilinmektedir³. Muscarella, XII. grup fibulalar hakkında hazırladığı kapsamlı çalışmasında değerlendirilen fibulaların pek çok alt gruba ayrıldığını ve bunların büyük çoğunluğunun doğrudan Frig yerel üretimi olduğu düşüncesine değinir ${ }^{4}$.

XII. gruba dahil edilen Frig fibulaları tipolojik açıdan Tip 2, 2A, 2B, 3, 4, 5, 7, 7A,

1 Oscar White Muscarella, "Frig Fibulaları/Phrygian Fibulae”, Friglerin Gizemli Uygarlığı, İstanbul 2007, s. 173.

2 Konu hakkında kapsamlı bilgi için bkz. Ertuğrul Caner, Fibeln in Anatolien: Prähistorische Bronzefunde: Abteilung XIV, München 1983, s. 29-31.

3 E. Caner, a.g.e., s. 3-26; Oscar White Muscarella, Phrygian Fibulae From Gordion (No. 4), London 1967a, Appendix C.

4 O. W. Muscarella, a.g.e., s. 59. Metinde anılan güncel yer adları, konu ile ilgili çalışmalarda söz konusu illerde yer alan müzelerde bulunan ve kesin geliş yeri belli olmayan eserleri tanımlamak için kullanılmıştır. 
$8,9,11,13,13 \mathrm{~A}, 14$ ve 14A gibi farklı alt gruplarda incelenmektedir'5. Frigler tarafindan kullanılan en eski fibula tipi, Tip XII.7A grubudur ${ }^{6}$. Karakteristik özellikleri arasında "boynuzlu çengel uçlu" ve büyük, yassı ya da at nalı şeklinde yaylı olması sayılmaktadır . Fibulaların çoğu yay ile birlikte dökülmüş ve diğer Frig objelerinden de bildiğimiz silmelerle süslüdür ${ }^{8}$. Fibulaların erken evrelere tarihlenen örneklerinde yay kısmı dikdörtgen kesitli ince bir görünümdeyken zamanla kalınlaştığı ve üzeri kabaralarla bezenen bir görünüme kavuştuğu bildirilmektedir9 .

Frig fibulaları yalnız materyal açısından değil, betimleme elemanları açısından da Khorsabad, Persepolis ve İvriz'de yer alan kabartmalarla karşılaştırılabilir. İÖ 8. yüzyıl sonlarına tarihlenen "Khorsabad frizi" bilinen en iyi örneklerden biridir ve betimlenen kişinin giysisi üzerinde yer alan fibula, Muscarella tarafindan, Tip XII 7 grubuna dahil edilmiştir ${ }^{10}$. Bir diğer kabartma ise Persepolis Apadanası'ndadır ve İÖ 5. yüzyıl sonlarına tarihlenmektedir. Bu kabartma üzerinde I. Artakserkses'e hediyeler sunan 14 figürden ikisinin giysilerini tutturmak için fibula takıyor oluşu, bu figürlerin kimlikleri ile ilişkili sayılmış, kişilerin Frig kökenli oldukları düşünülmüştür ${ }^{11}$. Anadolu Arkeolojisi açısından büyük önem taşıyan İvriz Kabartması'nda tanrısı Tarhunza'nın karşısında duran Tabal kralı Warpalawaş'ın giysisi üzerinde yer alan geometrik desenler ve giysiyi tutturmak için kullandığı Frig fibulası krala gönderilmiş prestij hediyelerinden sayılmakta, dönemin sosyo-kültürel yapısı hakkında bilgiler sunmaktadir ${ }^{12}$.

\section{Tanrıça Sembolizminde Ucu Kıvrık Saç Motifinin Kısa Tarihi}

Eski Babil mühürlerinde tanrıça sembolizmi amacıyla kullanıldığı bilinen ucu kıvrık saç motifine, bugüne değin birbirinden farklı anlamlar yüklenmiştir. Tanrıça kültü ile ilişkisi şüphe götürmeyen söz konusu motifin, daha çok omega ${ }^{13}$, Hathor saç1 ${ }^{14}$,

5 O. W. Muscarella, a.g.e.

6 Maya Vassileva, "Early Bronze Fibulae and Belts from The Gordion Citadel Mound", The Archaeology of Phrygian Gordion, Royal City of Midas: Gordion Special Studies 7, Pennsylvania 2013, s. 111-126.

7 Maya Vassileva, "Frig Tunç İşlemeciliği”, Frigler, Midas'ın Ülkesinde, Anıtların Gölgesinde, İstanbul 2012, s. 322-323.

8 M. Vassileva, a.g.e., s. 323.

9 Veli Sevin, "Frigler”, Anadolu Uygarlıkları Ansiklopedisi, C. 2, İstanbul 1982, s. 248-274.

10 Oscar White Muscarella, "Fibulae Represented on Sculpture”, Journal of Near Eastern Studies, C. 26 (2), 1967b, s. 82-86. Gordion kentinin son kronolojik sonuçları 1şığında Muscarella tarafından İÖ 8. yüzyıl sonlarına tarihlenen fibula için İÖ 850 ve sonrasını önermek gerekmektedir. Zira Tip XII 7 grubu tahrip tabakası öncesine denk gelen erken tümülüslerden de bilinmektedir.

11 O. W. Muscarella, a.g.e., s. 88.

12 Winfried Orthmann, Untersuchungen zur Späthethitischen Kunst, Vol. 8, Bonn 1971, s. 487; Rainer Michael Boehmer, Die Kleinfunde aus der Unterstadt von Boğazköy: Grabungskampagnen 1970-1978, Berlin 1972, s. 46; Trevor Bryce, The World of The Neo-Hittite Kingdoms: A Political and Military History. Oxford 2012, s. 150 vd; M. Vassileva, a.g.e., s. 323.

13 Heinrich Zimmern, Die Göttersymbole des Nazimaruttaš-Kudurru, Leipzig 1906, s. 33 vd.

14 William John Hinke, A New Boundary Stone of Nebuchadrezzar I From Nippur, Philadelphia 1907, s. 121. 
terazi ${ }^{15}$, kuyruklu yild $1 \mathrm{z}^{16}$, boyunduruk ${ }^{17}$, saç band $1^{18}$, peruk ${ }^{19}$, inek rahmi ${ }^{20}$ ve y1lan ${ }^{21}$ gibi tanımlarla değerlendirildiği görülmektedir.

Ucu kıvrık saç motifi, ya da yaygın, fakat çok da doğru bulmadığımız tanımıyla omega sembolü $(\Omega)$, ilk olarak Sümer tanrıçası Ninhursag ve onun etkileşimindeki Mısır tanrıçası Hathor'un sembolizminde karşımıza çıkmaktadır ${ }^{22}$. Bununla beraber kimi çalışmalarda anılan sembolün doğrudan Ay tanrısı Sin ile ilişkilendirildiği görülmektedir. Samsat'ta bulunan bir mühür üzerinde Sin, elinde söz konusu sembolle bir arada betimlenmiştir ${ }^{23}$.

Ana tanrıça formunda tapınım gördüğü bilinen Ninhursag kültü, söz konusu sembolün ortaya çıkışında öncül rolüyle son derece önemlidir. Ubaid Dönemi içlerinde tapınım görmeye başlayıp kültü zamanla tüm Yakındoğu’ya yayılan Tanrıça Ninhursag, farklı kültürlerde "dağların kraliçesi", "tanrıların anası" ve "tüm çocukların anası" olarak anılmıştır ${ }^{24}$. Yaklaşık 1500 yıldan fazla bir süre tapınım görmüş olan Ninhursag'ın ana tapınım merkezleri arasında Ur, Mari, Keş, Adab, Hiza sayılabilmektedir.

Sümer panteonunun yedi ana kültünden birini oluşturması itibariyle dönem toplumunda büyük önem verilen tanrıça, yukarıda değinmiş olduğumuz üzere daha çok omega olarak tanımlanan bir sembol ile betimlenmekte, kendisinden ziyade doğrudan sembolü aracılığıyla yansıtıldığı materyal kültür ögeleri de bulunmaktadır. Sınır taşı olarak kullanıldığı bilinen kudurru'lar bunun en önemli örnekleri arasında yer $\operatorname{almaktadir}^{25}$.

Anadolu'da doğrudan Ninhursag kültü ile ilişkili ögeler, Orta Tunç Çağı'ndan

15 Jeremy Black, Anthony Green, Gods, Demons and Symbols of Ancient Mesopotamia: An Illustrated Dictionary, London 1992, s. 146.

16 Ilse Fuhr, Ein Altorientalisches Symbol: Bemerkungen zum sogenannten "omegaförmigen Symbol” und zur Brillenspirale, Wiesbaden 1967, s. 4vd.

17 Leonard William King, Babylonian Boundary-stones and Memorial-tablets in The British Museum, London 1912, s. 15 vd; Susanne Berndt Ersöz, "Cutting The Gordian Knot: The Iconography of Megaron 2 at Gordion", Opuscula-Annual of The Swedish Institutes at Athens and Rome, C. 8, Rome 2015, s. 114.

18 J. Black, A. Green, a.g.e., s. 146.

19 J. Black, A. Green, a.g.e., s. 146.

20 Henri Frankfort, “A Note on The Lady of Birth", Journal of Near Eastern Studies, C. 3-3, 1944, s. 198 vd.

21 Sevgi Dönmez, "Eski Yakındoğu’da Yılanlı Tanrıça Kültü Üzerine Bir Değerlendirme”, Tarih İncelemeleri Dergisi, C. XXXII/2, 2017, s. 411.

22 Ucu kıvrık saç motifinin bilimsel çalışmalarda Hathor tipi saç olarak tanımlanmasına karşın, Ninhursag kültünün Hathor'dan daha önceye dayandığı bilinmektedir. Michael Jordan, Dictionary of Gods and Goddesses, New York 2004, s. 115, 221.

23 Nimet Özgüç, “Samsat Mühürleri”, Belleten, C. 51, 1987, s. 436, Res. 13.

24 Gwendolyn Leick, A Dictionary of Ancient Near Eastern Mythology, London 1991, s. 132; Eric Orlin, Routledge Encyclopedia of Ancient Mediterranean Religions, Abington 2015, s. 656.

25 W. J. Hinke, a.g.e.; Ursula Seidl, Die Babylonischen Kudurru-Reliefs: Symbole Mesopotamischer Gottheiten, Freiburg 1989. 
itibaren görülmeye başlanmaktadır. Asurlu tüccarların yoğun ticari faaliyetleri sonucunda tanınan tanrıçanın ucu kıvrık saçlarının betimlendiği damga mühürlerin Anadolu'da Acemhöyük ${ }^{26}$ (G. 1a), Alişar ${ }^{27}$, Çavlum ${ }^{28}$, Gordion ${ }^{29}$, Karahöyük ${ }^{30}$ gibi merkezlerde -özellikle çocuk mezarlarında- tespit edilmiş örnekleri dikkat çekmektedir. Bilgen, söz konusu sembolün dönem içerisinde salt damga mühürlerde değil, aynı zamanda kolye sallantısı gibi eklentilerde de gözlemlendiğine dikkat çekmektedir. Bu sembol betimli objeleri kullanan ya da mezarlara bırakan bireylerin, dönemin Ninhursag rahipleri olabileceği düşünülmektedir ${ }^{31}$. Bu noktada, Ninhursag'` betimleyen eserler üzerinde, tanrıçanın ucu kıvrık saç biçimli eklentisi olan kolyelerle betimlendiği örnekler önem kazanmaktadır ${ }^{32}$ (G. 1b). Nitekim Eski Mısır'da da kadınların, hamilelikleri esnasında benzer biçimli kolyeler taktıkları da bilinmektedir ${ }^{33}$.

Anadolu'da Orta Tunç Çağ sonlarına doğru figüratif anlatıda yer bulmaya başlayan ucu kıvrık saç motifi, Geç Tunç Çağı'nda özellikle sphenkslerde izlenebilmektedir ${ }^{34}$. $\mathrm{Bu}$ süreçte söz konusu sembol kimi zaman kanatlı güneş kurslarının merkezinde yer alan diskleri çevreler şekilde ${ }^{35}$, kimi zamansa eril panteonun egemen güçlerinden dağ tanrılarının gögüslerine kadar uzanan saçlarında görülmeye devam etmiştir ${ }^{36}$.

İklimsel değişikliklere bağlı olarak gelişen ve yaşanan geniş çaplı kuraklığa bağlı olarak, Frig kültürünün şekillenmesine neden olan Geç Tunç Çağı'ndan Erken Demir Çağ'a geçiş sürecinde Hititler'in tarih sahnesinden çekildikleri bilinmektedir. Buna karşın, uygarlı̆̆ın kültürel izleri Anadolu'nun özellikle Güney ve Güneydoğusu ile Kuzey Suriye'de kurulan bir dizi kent devleti aracıllğıyla bir süre daha yaşamaya devam etmiştir. Söz konusu kent devletlerinin kültürel yapılanması, İÖ 2. binyıldan köklenen birikimin izlerini yansıtmaya devam etmiş, bir süre sonra bölgeye ulaşan yeni halkların da katılımıyla melez özellikler sergilemeye başlamıştır ${ }^{37}$.

26 Michael Rainer Boehmer ve Hans Gustav Güterbock, Glyptik aus dem Stadtgebiet von Boğazköy: Grabungskampagnen 1931-1939, 1952-1978, Berlin 1987, s. 41, Abb. 27 h-i.

27 Hans Henning von der Osten, The Alişar Hüyük Seasons of 1930-1932 Part II, Chicago 1933, Fig. 479.

28 Nejat Bilgen, "Frigya'da Ninhursag İnancının İpuçları", Anadolu Üniversitesi I. Uluslararası Dünden Bugüne Eskişehir Sempozyumu: Siyasal, Ekonomik, Sosyal ve Kültürel Yapı, Eskişehir 2005, s. 357361, Şek. 2-z.

29 Machteld Johanna Mellink, A Hittite Cemetery at Gordion, Philadelphia 1956, Pl. 23-n.

30 Sedat Alp, Konya Civarında Karahöyük Kazılarında Bulunan Silindir ve Damga Mühürleri, Ankara 1994, s. 207, Şek. 162-164.

31 N. Bilgen, a.g.e., s. 359.

32 Lotte Motz, The Faces of Goddess, New York 1997, s. 94, Fig. 32.

33 Stephanie Lynn Budin, Images of Woman and Child from the Bronze Age: Reconsidering Fertility, Maternity, and Gender in the Ancient World, Cambridge 2011, s. 204.

34 Önder Bilgi, Anadolu'da İnsan Görüntüleri: Klasik Çağ Öncesi, İstanbul 2012, s. 378, Res. 1087.

35 Hatice Kübra Ensert, "M.Ö. İkinci Binde "Kanatlı Güneş Kursu” İle Taçlandırılmış Anadolulu Hitit Figürleri", Anadolu/Anatolia, C. 28, 2005, s. 25 vd.

36 Peter Neve, Hattuša-Stadt der Götter und Tempel: Neue Ausgrabungen in der Hauptstadt der Hethiter, Darmstadt 1992, Abb. 82.

37 W. Orthmann, a.g.e. 
Asur, Arami ve Fenike etkilerinin gerek toplumsal yaşam, gerekse sanat alanında yenilikleri beraberinde getirmesine karşın, Orta Tunç Çağı'ndan bu yana görülen ucu kıvrık saç motifi bu dönemde yeniden, Tunç Çağı'nda baskılanan ve gücünü eril tanrılarla paylaşmak durumunda kalan tanrıça inancıyla, başta "Kubaba" betimleri olmak üzere yeniden görülmeye başlanmıştır. Anadolu'da, kökleri Neolitik Çă̆’a değin giden "ana tanrıça" inancının uzantısı niteliğinde yeniden güçlenen kültün gelişimi, başta Kargamış ve Melid Krallıkları olmak üzere, devrin sanat yapıtları ve yazılı kaynaklarında belirgin olarak izlenebilmektedir ${ }^{38}$.

Demir Çağ’da ucu kıvrık saç motifiyle betimlenen tanrıça görünümü, Walastin yakınlarından elde edilen ve İÖ 11. yüzyıla tarihlenen Meharde Steli'nde izlenmeye başlanmaktadır (G. 2a). Tanrıça Kubaba burada ilk kez ucu kıvrık saç motifi ile betimlenmiştir. Stel üzerinde yer alan yazıtla, yerel dilde Kupapiya olarak anılan tanr1ça, bir niş içerisinde cepheden ve ayakta, altında kutsal hayvanı aslana basar şekilde betimlenmiştir ${ }^{39}$.

Meharde Steli’ni takip eden süreçte tanrıça, İÖ 10. yüzyıla tarihlenen Zincirli ortostatlarında benzer bir saç şekliyle profilden gösterilmiştir ${ }^{40}$ (G. 2b). Bu yüzyılın sonlarında tanrıça Melid'de bir stel üzerinde benzer bir saç motifiyle tekrar betimlenmiştir ${ }^{41}$ (G. 2c). Melid Steli'nde yalnızca tanrıça değil, aynı zamanda sahnenin üst kısmını sınırlandıran kanatlı güneş kursunda da aynı sembolün, kursun merkezinde yer alan diski çevreler halde bulunması dikkat çekmektedir. Benzer bir uygulama İÖ 900'lere tarihlenen Birecik Steli'nde de görülmektedir (G. 2d). Burada tanrıçanın hem polos altından aşağı doğru sarkan saçları, hem de üstünde yer alan güneş kursunun disk biçimli gövdesi, ucu kıvrık saç motifini yansıtır niteliktedir ${ }^{42}$. Ucu kıvrık saç modeli ile ilgili son örnek Kargamış’tan gelmektedir. Diğer Geç Hitit merkezlerinden tanıdığımız kompozisyonun devam ettiği, orthostat üzerinde betimlenen ve profilden işlenen tanrıçanın polosundan aşağıya doğru sarkan saçının iki sıra ve uçlardan kıvrımlı olacak şekilde düzenlendiği görülmektedir ${ }^{43}$ (G. 2e).

\section{Frig Sanatında Ucu Kıvrık Saç Motifinin Yansımaları}

Frigler, Erken Demir Çağ içlerinde Anadolu’ya Balkanlardan giriş yaptığı düşünülen, buna karşın kökeni oldukça tartışmalı bir topluluktur. Doğu'nun yazılı kaynaklarında Muşki ya da Mu-şa-ka-za, Batı kaynaklarında ise Frig olarak tanımlanan top-

38 T. Bryce, a.g.e.

39 John David Hawkins, "Cilicia, the Amuq, and Aleppo", Near Eastern Archaeology, C. 72, 2009, s. 170.

40 Maurits Nanning van Loon, Anatolia in The Earlier First Millennium B.C. Iconography of Religions, Leiden 1991, Pl. XV.

41 W. Orthmann, a.g.e., Taf. $42 f$.

42 W. Orthmann, a.g.e., Taf. 5c.

43 W. Orthmann, a.g.e., Taf. 23 b. 
luluğun kültürel izleri Anadolu'nun öncül ve çağdaş kültürlerinden derin izler taşır. Frig kültürünün oluşumunda tanrıça inancının önemli bir yer tuttuğu görülmektedir. Neredeyse baş tanrıları konumunda olan "Matar-Kybele" kültünü doğrudan Geç Hitit Kent Devletleri’nden öğrenerek, kendi düşün dünyalarında geliştiren Frigler, doğanın bizzat kendisi olarak gördükleri tanrıçalarını hem antropomorfik olarak üç boyutlu ya da yüksek kabartma biçiminde, hem de idol olarak sanat yapıtlarında yansıtmışlardır.

Frig "Matar-Kybele" ikonografisi, Geç Hitit etkili, fakat Frig katkılarıyla özgünleştirilmiş biçemde karşımıza çıkar. Daha çok Dağlık Frigya Bölgesi'nde tanrıça adına oluşturulmuş fasadlarda, yüksek kabartma ve basamaklı anttlar üzerinde yer alan idoller aracılığıyla tanıdığımız tanrıçanın heykelleri oldukça az sayıdadır. Tanrıça adına oluşturulmuş az sayıdaki heykellerden biri Boğazköy Frig katlarında ele geçmiştir. Kent kapısının hemen yanında, yardımcılarıyla bir arada betimlenen tanrıçanın ucu kıvrık saç modeli, karakteristik yansının uzantısı niteliğindedir ${ }^{44}$ (G. 2f).

Frig başkenti Gordion/Yassıhöyük'te uzun yıllara dayanan çalışmalar, MatarKybele inancında ucu kıvrık saç motifinin önemini yansıtır nitelikte sunduğu farklı tipte eserler itibariyle önemlidir. Buranın yanı sıra, sonradan Friglerin başkenti olduğuna inanılan Pteira kenti ile bir tutulan Kerkenes ${ }^{45}$ ve Ankara'da dağınık durumda ele geçen bir dizi eser üzerinde, Frig tanrıçasının ucu kıvrık saç motifiyle betimlendiği bilinmektedir.

Gordion'da ucu kıvrık saç motifli tanrıça betimi ilk önce İç Kale, Teras Binası 2'de ele geçen Kuzey Suriye kökenli fildişi at koşum takımı parçası ile gözlemlenmekte$\operatorname{dir}^{46}$ (G. 2g). Eser üzerindeki tanrıça görüntüsü, Doğu Akdeniz'in güçlü "hayvanlar hakimi” tanrıçayı çağrıştırır niteliktedir. Tanrıçanın betim özellikleri arasında yer almasa da, polosunun üst kısmındaki güneş kursunun disk biçimli merkezinin, Yakındoğu geçmişinden iyi bilinen ucu kıvrık saç motifi ile sarmalandığı görülmektedir.

Frigler'de tanrıçanın idol şeklinde betimlenmesine dair düşüncenin tam olarak ne zaman başladığı bilinmese de, kentin sunduğu son kronolojik değişiklikler, anılan durumun tahrip tabakasından hemen önce şekillenmeye başladığını gösterir bulgular taşmaktadır. ÏÖ 9. yüzyıl sonlarına tarihlenen ve Megaron 2'nin dış duvarlarında tespit edilen, çizilerde karşılaşılan idol ${ }^{47}$ (G. 3a), Frig düşüncesinde tanrıça-idol görünümünün olası erken örneklerini sunması itibariyle önemlidir.

44 Kurt Bittel, "Untersuchungen auf Büyükkale. Das Archiv im Gebäude K. Das phrygische Burgtor in vx/ 6-7." MDOG, C. 91, 1958, s. 57 vd; Friedhelm Prayon, Phrygische Plastik: Die früheisenzeitliche Bildkunst Zentral-Anatoliens und ihre Beziehungen zu Griechenland und zum Alten Orient, C. 7, Tübingen 1987, Taf. 3a-c.

45 Geoffrey Summers, Françoise Summers, "Kerkenes Dağ”, Frigler, Midas'ın Ülkesinde, Anıtların Gölgesinde, In the Land of Midas, In the Shadow of Monuments, İstanbul 2012, s. 162.

46 F. Prayon, a.g.e., Taf. 44c.

47 Lynn Roller, The Incised Drawings from Early Phrygian Gordion, Philadelphia 2009, s. 56-58. 
Frig tanrıçasının idollerindeki ucu kıvrık saç tipi ile, farklı merkezlerden gelen stel ve basamaklı anıtlar üzerindeki betimlemelerde karşılaşılmaktadır. Ankara Sincan yakınlarında bulunmuş ve İÖ 8-7. yüzyıllara tarihlendirilen bir Frig steli üzerinde betimlenen ikiz tanrıçaların tek bir ortak saç örgüsünü paylaştıkları, saçın her bir idolün bir yanında ucu kıvrık şekilde sonlandığı görülmektedir (G. 3b). Benzer bir yaklaşım Dağlık Frigya'nın en bilindik basamaklı anıtlarından "Kitabeli Sunak" (G. 3c) üzerinde, kazıma çizgiyle oluşturulmuş tanrıça görüntülerinde de izlenebilmektedir ${ }^{48}$. Dağlık Frigya'da idollerin yanı sıra, basamaklı anıtların taht biçimli arkalık kısımlarının tanrıçayı yansıtır şekilde düzenlenmiş olduğu düşünülmektedir ${ }^{49} . \mathrm{Bu}$ düşüncenin temel dayanağı, söz konusu arkalığın her iki yanında duran aslanların varlığıdır. Tarihsel süreçte, ayrılmaz kutsal hayvanı olan aslan ile olan birlikteliği iyi bilinen tanrıça kimliğinin, sözü edilen tahtların, Köhnüş 2 no'lu anıt örneğinde olduğu üzere kazıma çizgilerle oluşturulmuş ucu kıvrık saçlarla aktarılmaya çalışıldığ 1 görülmektedir ${ }^{50}$ (G. 3d).

Frig idollerinin ucu kıvrık saç yapısı ile bağlantısının geç örnekleri Kerkenes kazılarından elde edilmiştir. Özellikle Kapadokya Kapısı olarak adlandırılan bölümde yoğunlaşan kazı çalışmaları sonucunda saptanan basamaklı alan ve üzerinden elde edilen üç boyutlu idol görünümlü steller, yine tanrıçanın ucu kıvrık saçlarını yansıtır yapıda oluşturulmuştur. Kerkenes’te tespit edilen idol ve stel örneklerinde ucu kıvrık saçların yalın ya da kazınarak işlenmiş halde, iki farklı üslupta değerlendirildiği görülmektedir ${ }^{51}$ (G. 3e).

Frig sanatında, tanrıça görüntülerinin doğrudan yansıtıldığı heykel, yüksek kabartma ve idollerin dışında, ahşap eserler de önemli bir grubu oluşturmaktadır. MM Tümülüsü (IÖ 740'lar) servis standlarının ön yüzlerinde yer alan disk içi rozet motifleri ve rozetlere bağlantılı olarak standın her iki yanına doğru uzayan kıvrık ayak biçimli uzantılar, temsili "Matar-Kybele" görüntüsü olarak tanımlanmış, söz konusu ayakların, tanrıçanın eşlikçisi aslanlara ait olduğu belirtilmiş̧iir ${ }^{52}$ (G. 3f), Simpson daha sonraki çalışmasında, söz konusu standların bu haliyle "taşınabilir kült anıtı" halini aldıklarını düşüncesine değinmişstir ${ }^{33}$.

Ucu kıvrık saç, ya da araştırmacılar tarafından sıklıkla bilinen haliyle "omega

48 Taciser Tüfekçi Sivas, Eskişehir-Afyonkarahisar-Kütahya İl Sınırları İçindeki Phryg Kaya Anıtları, Eskişehir 1999, s. 126-127, Lev. 125-126.

49 T. Tüfekçi Sivas, a.g.e., s. 119 vd.

50 T. Tüfekçi Sivas, a.g.e., s. 131-132, Lev. 147-150.

51 Geoffrey Summers, "Phrygian Expansion to The East: Evidence of Cult from Kerkenes Dağ", BaM, C. 37, 2006, s. 649, Taf. 1a-c.

52 Elizabeth Simpson, Krysia Spirdowicz, Gordion Wooden Furniture: The Study, Conservation and Reconstruction of The Furniture and Wooden Objects from Gordion, 1981-1998, Ankara 1999, s. 43.

53 Elizabeth Simpson, “Gordion Mobilya ve Ahşap Eserleri”, Frigler, Midas'ın Ülkesinde, Anıtların Gölgesinde, İstanbul 2012, s. 344. 
motifi”, Frig mühürlerinden de tanınmaktadır. Ayrıntılı çalışmaları Dusinberre tarafindan gerçekleştirilen ve omega tutamakl damga mühürler olarak tanımlanan ${ }^{54}$ mühürlerin yüksek kaide üzerine ucu kıvrık saç motifini anımsatır halka tutamaklarla bezendiği görülmektedir (G. 3g). Tartışmalı olsa da, genellikle Orta Frig Dönemi’ne (İÖ 800-540) ait söz konusu eser grubunun baskı yüzlerinde yer alan figürlerin biçem özellikleri İÖ 770’e tarihlendirilen P Tümülüsü ahşap hayvan heykelcikleri ile karş1laştırılmakta ve büyük benzerlikler taşıdığı belirtilmektedir ${ }^{55}$.

Ucu kıvrık saç motifinin Frig sanatı ve dini dünyasındaki yerine dair bir diğer bulgu, başkent Gordion'da yer alan ve tanrıça Matar-Kybele kültünün merkezi olabileceği düşünülen "Megaron 2" yapısının tabanında tespit edilen çakıl taşı mozaiklerden gelir. Bu alanda gerçekleştirilen çalışmalarda, İÖ 9. yüzyıl sonlarında yanmış olduğu bilinen yapının tabanında keşfedilen son derece karmaşık desenli mozaik, ilk önce Young tarafından incelenmiştir ${ }^{56}$. Mozaik tabanın merkezinde yer alan ve “ocak" şeklinde değerlendirilen yuvarlak boşluk dikkat çekicidir. Young'ın ocak olarak tanımladığı ve tüm geometrik örgelerin merkezinde yer alan bu yuvarlak boşluğun hemen üzerinde, Frig sanatında sıklıkla tanrıça ikonografisinin bir uzantısı niteliğinde sembolleştirilen daire içi rozet motifi yer almaktadır (G. 3h). Yuvarlak ocağın (?) alt sağ-sol yanlarında yer alan uzun ve ince dikdörtgen boşluk bulunmaktadır. Bu boşlukların dairenin dışındaki konum özellikleri, ocak olarak tanımlanan küresel boşluğun üstünde yer alan rozet motifi ile bir arada değerlendirildiğinde, Simpson ve Spirdowicz tarafindan incelenen servis standlarındaki temsili "Matar-Kybele" görüntüsüyle büyük uyum sergilediği anlaşılmaktadır. Young tarafından ocak olarak tanımlanan alanda yer alan boşluğun Frig ahşap repertuarından tanımadığımız, fakat olasilıkla yangından etkilenerek yok olmuş, oval, kakmalı ve "Matar-Kybele" inancını yansıtan bir ahşap eserle doldurulmuş olması son derece olasıdır. Megaron 2'nin hemen dış kısmında tespit edilen akroter ve yapının dış duvarlarında yine tanrıça kültü ile bir arada değerlendirilebilecek unsurlar sunan çizilerin varlığ $1^{57}$, bir bütün olarak yapının Gordion kent merkezindeki Matar-Kybele tapınağı olarak kullanım görmüş olduğunun en güçlü kanıtları olarak değerlendirilmelidir.

Ucu kıvrık saç motifinin Frig Matar-Kybele'si ile bağlarına dair yukarıda ele aldığımız örnekler dışında, tanrıçanın önemli eşlikçilerinden biri olduğunu bildiğimiz gryphonların da ucu kıvrık saç motifi kapsamında ayrıca değerlendirilmesi gerekmektedir. Başkent Gordion'da ele geçen protom gryphonların ${ }^{58}$ Frig düşüncesinde tanrıça ile birliğini en net yansıtan eser, Etlik Steli'nde niş içerisinde poloslu tanrıça-

54 Elspeth Dusinberre, Gordion Seals and Sealings Individuals and Society, Pennsylvannia 2005, s. 23.

55 E. Dusinberre, a.g.e., s. 23, Fig. 31, Cat. No. 21-10351 SS 258.

56 Rodney Stuart Young, "Early Mosaics at Gordion”, Expedition, C. 7/3, 1965, s. 4 vd.

57 L. Roller, a.g.e.

58 F. Prayon, a.g.e., Taf. 20e-f. 
nın hemen yanında betimlenen, ayakta duran gryphondur ${ }^{59}$ (G. 4a). Frig sanatında yer bulan ortostatlar üzerinde, tanrıçanın aslan ve boğa gibi diğer kutsal hayvanlarıyla bir arada betimlenen gryphonların, Emirdağ-Daydalı gibi örnekler aracılığıyla Frig coğrafyasının farklı noktalarında da sevilerek yansıtıldığı görülmektedir ${ }^{60}$.

Frig sanatında gryphon betimleri, Orta Tunç Çağı'ndan itibaren Anadolu'da varlığı bilinen sfenkslerde görülen ucu kıvrık saç motifi ile büyük benzerlikler taşır. Özellikle Ankara ortostat grubu ${ }^{61}$ (G. 4b) ve Daydalı' da ${ }^{62}$ (G. 4c) örneklerindeki gryphonların son derece belirgin bir şekilde ucu kıvrık saç motifi ile betimlendiği görülmektedir. Bununla beraber Etlik Steli'nde de ayakta duran gryphonun üstünde Frig sanatında çokça karşılaşmadığımız bir öge olan kanatlı güneş kursu bulunmaktadır. Her ne kadar stel üzerinde yer alan güneş kursunda kıvrık saç örgüsü ile karşılaşılmasa da, benzer örneklerinde kanatlı güneş kursunun da ucu kıvrık saç motifini barındırdığının bilinmesi, sembolizmin yansıtılmasında farklı biçemlerin de olabileceğini düşündürmektedir. Nitekim Vasilleva, idollerde görülen ucu kıvrık saç tipinin Hitit İmparatorluk Dönemi kanatlı güneş kurslarıyla etkileşim sonucunda Frig sembolizmine girmiş olabileceğine değinmektedir ${ }^{63}$.

\section{Frig Tipi Fibulalarda Tanrıça Sembolizmi}

Daha önce değindiğimiz üzere önce Blinkenberg ${ }^{64}$, daha sonra Muscarella ${ }^{65}$ ve Caner ${ }^{66}$ tarafından değerlendirilen Frig tipi fibulalar, yaklaşık olarak İÖ 840'l1 yıllardan itibaren üretilmeye ve kullanılmaya başlanmış, başta süsleme geleneği ve genel yapıları itibariyle sergiledikleri belli başlı tipolojik farkl111klar neticesinde 15 alt gruba ayrılarak incelenmiştir. Gordion yeni kronolojisi 1şığında net tarihler sunan tümülüslerden elde edilen örnekleri 1şığında değerlendirildiğinde söz konusu alt gruplar arasında en erken örnekleri İÖ 840'lardan itibaren görülmeye başlanan Tip 7A, Tip 3 ve Tip 13'ün oluşturduğu anlaşılmaktadır. İÖ 830'lardan itibaren Tip 2, İÖ 810'lardan itibaren Tip 4 Frig tipi fibulalar üretilmeye başlanır. İÖ 780’lere gelindiğinde fibula alt gruplarında bir artış yaşanmış, bu tarihten itibaren önceki fibula alt gruplarına Tip 5, Tip 7 ve Tip 9 eklenmiştir. Anılan alt grupları İÖ 740’lardan itibaren Tip 5 ile Tip 11 ve İÖ 700'lerde üretimine başlanan Tip 2A izlemiştir.

59 F. Prayon, a.g.e., Taf. 9-b.

60 Hasan Tahsin Uçankuş, “Emirdă̆ı'nda Yeni Bulunan Bir Hitit Kabartması”, Belleten, C. 35/139, 1971, Lev. I-VI, X.

61 Ekrem Akurgal, Phrygische Kunst, Archäologisches Institut der Universität Ankara, Ankara 1955, s. 68; F. Prayon, a.g.e., Taf. $7 \mathrm{~b}$.

62 H. T. Uçankuş, a.g.e., Lev. I-VI, X.

63 Maya Vassileva, "Phrygian Rock-Cut Thrones, 'Idols' and Phrygian Royal Symbolism", Thracia, C. 18, 2009, s. 117.

64 Christian Sørensen Blinkenberg, Fibules Grecques et Orientales, Kobenhavn, 1926, s. 204-230.

65 Oscar White Muscarella, Phrygian Fibulae From Gordion (No. 4), London, 1967a.

66 E. Caner, a.g.e. 
Frig dünyasında fibulalar, çağdaşı pek çok çevre kültürün aksine, günlük yaşamın bir parçası olmaktan çok, bir prestij unsuru olarak sayılmışlardır. Frig başkenti Gordion'da yürütülen çalışmalar, söz konusu eserlerin önemli bir kısmının soylu bireylere ait tümülüslerde tespit edildiğini göstermesi açısından son derece değerlidir. Uzun yıllara dayanan çalışmalar neticesinde henüz fibulaların üretildiği atölye ya da kalıplar bulunamamış olsa da araştırmacılar tarafından Gordion, fibula üretim merkezleri arasında sayılmaktadır ${ }^{67}$. Demir Çă̆ Anadolu'sunun önemli merkezlerinden olan Kaman-Kalehöyük ${ }^{68}$ ve Smyrna ${ }^{69}$ gibi merkezlerde tespit edilen Frig tipi fibula kalıpları, söz konusu prestij ürünün Frig çekirdek coğrafyası sınırlarını aşarak büyük bir beğeniyle lokal merkezlerde de üretildiğinin en önemli göstergeleri arasındadır.

Tanrıça Matar-Kybele'nin önceki bölümlerde ayrıntılı bir şekilde değindiğimiz ucu kıvrık saç motifi ile bağlantısının yansımaları bize göre Frig tipi fibulalarda değişmez bir unsur olarak karşımıza çıkan iğne tutamak plakalarında izlenebilmektedir. Ayrıntılı tipolojik ayrımları önceki yıllarda gerçekleştirilen önemli çalışmalarda değinilmeyen bu özelliğge dair yorumumuz öncelikle Simav Yöresi'nden elde edilen ve en erken örnekler arasında sayılan Tip 7A Frig fibulalarında gözlemlenmektedir.

Tip 7A fibulalar genellikle yarım ay biçimli, çoğunlukla dörtgen kesitli yassı bir gövdeye sahiptir. Diğer tüm Frig tipi fibulalarda olduğu üzere Tip 7A fibulalarında da gövde kısmı her iki taraftan kimi zaman boncuk, disk, silme, düğme ve abacus gibi, bir dizi süsleme ile bezenmektedir. Fibulanın sağ ya da sol taraflarındaki bir dizi bezemeden sonra, uç kısımlarında yer alan zemberek ve ona bağlı iğne ile diğer tarafta iğneyi karşılar şekilde biçimlendirilen iğne tutamak plakası yer almaktadır.

Frig tipi fibulalarda yer alan iğne tutamak plakaları, daha önceki çalışmalarda çoğunlukla "boynuz" ya da "pençe" şeklinde tanımlanan ${ }^{70}$ karakteristik bir özellik sergiler. Bu özellik salt Tip 7A'da değil, takip eden tüm fibula alt gruplarında, bazı farkl1lıklarla izlenebilmektedir. Tutamak kısımlarının özellikle Simav yöresinden elde edilen erken örnekleri bize yukarıda değinilen sıfatları değil, "Matar-Kybele" ikonografisinin önemli yorumlarından ucu kıvrık saç motifini yansıttığını düşündürmektedir. Caner tarafindan yayınlanan $\operatorname{Simav}^{71}, \mathrm{Uşak}^{72}$ (G. 5a2), Eskişehir ${ }^{73}$ (G. 5a3) ve aynı görüntüyü sergileyen, fakat nereden elde edildiği bilinmeyen benzer örnek-

67 O. W. Muscarella, a.g.e.; E. Caner, a.g.e.

68 Masao Mori ve Sachihiro Omura, “1988 Kaman-Kalehöyük Kazıları”, KST, C. 11, 1990, s. 337, 347, Res. 9-6.

69 O. W. Muscarella, a.g.e., s. 49.

70 O. W. Muscarella, a.g.e.; Maya Vassileva, “Frig Tunç İşlemeciliğii”, Frigler, Midas'ın Ülkesinde, Anıtların Gölgesinde, İstanbul 2012, s. 323.

71 E. Caner, a.g.e., Taf. 16-211.

72 E. Caner, a.g.e., Taf. 37-483.

73 E. Caner, a.g.e., Taf. 29-361A. 
ler ${ }^{74}$ aracılığıyla izlenebilen ve Tip 9 fibulalarda $^{75}$ (G. 5a4) iyice belirginleşen içe kıvrımlı halka biçimli uzantıların Matar-Kybele temsiline ait olduğu, değerlendirdiğimiz diğer Frig eserlerinde sergilenen kimi ögelerle karşılaştırıldığında çok daha net bir biçimde görülebilmektedir.

Simav, Uşak, Eskişehir örnekleri 1şığında başta ucu kıvrık saç olmak üzere MatarKybele ikonografisindeki kimi uygulamaların Frig tipi fibulalarda yer bulduğuna dair düşüncelerimizin en önemli dayanaklarından birisi önce Simpson ve Spirdowicz ${ }^{76}$, daha sonra da Vassileva tarafindan değerlendirilen ${ }^{77}$ Frig ahşap servis standlarında yansitılan temsili Matar-Kybele idolleridir.

Servis standlarının ön yüzlerinde yer alan disk içi rozet motifleri ve standın her iki yanına doğru uzayan kıvrık ayak biçimli, Matar-Kybele'nin kutsal hayvanı aslanları yansıttığına inanılan uzantılar, temsili Matar-Kybele görüntüsü olarak tanımlanmak$\operatorname{tad}^{78}{ }^{78}$. Taşınabilir bir kült anıtı olarak değerlendirilen ${ }^{79}$ söz konusu eserin sunduğu kimi özellikler Frig tipi fibulaların iğne tutamak plakası ve bağlantılı kanca kısmı ile oldukça benzer yapıdadır.

Servis standları ve fibulaların iğne tutamak plakaları arasında gözlemlediğimiz ortak özelliklerden ilki ve en önemlisi, her iki grup eserin de temsili olarak MatarKybele'yi yansitıyor oluşudur. Her iki grup eser üzerinde tanrıça, genel şemadan ayrılır şekilde, bir çerçeve içerisinde betimlenmiştir. Servis standında kazınarak oluşturulan bu görünüm, iğne tutamak plakasında yivli alanlarla sunulmuştur. İğne tutamak plakasında yivle açılan iki ya da üç sıra kanal, merkezde tek ya da iki sıra halinde dikey yönlü bir yükselti sağlamıştır. Böylece, tanrıçanın MM Tümülüsü servis standındaki temsili görüntüsü ${ }^{80}$ ve Kerkenes steliyle ${ }^{81}$ benzer yapıda biçimlendirilen ana gövdesini oluşturulmuştur (G. 5b1-3). Ana gövde, her iki yandan, iğne tutamak plakasının kanca kısmına doğru içe dönük kıvrımlı bir geçiş yapmaktadır. $\mathrm{Bu}$ özellik itibariyle, fibulalar, servis standlarında karşılaşılan bir başka özellik olan “aslan pençesi” şeklinde sonlanışı vurgular şekilde sunulmuştur. Buna göre, ana gövdenin her iki yanından uzayan kanallar aslanın ayaklarını, kanca kısmı ise pençe görünümünü sunuyor olmalıdır. Plaka üzerinde açılan derin yivlerle oluşan kanallı yapının ortasında tek ya da çoğunlukla iki sıra halinde kalan yükseltinin, tekil ya da ikiz tanrıçanın gövde kısmının üzerinde, olasılıkla tanrıçanın başını yansıtır şekilde üçgen bir süsleme ögesi yer almaktadır. Bunun üzerinde, tanrıça ikonografisinin de-

74 E. Caner, a.g.e., Taf. 16-210, 212-214; Taf. 23-291A.

75 O. W. Muscarella, a.g.e., Pl. VI-31-32, P1. VII-33-36; E. Caner, a.g.e., Taf. 33-35.

76 E. Simpson, K. Spirdowicz, a.g.e., s. 39-42.

77 M. Vassileva, a.g.e., s. 323.

78 E. Simpson, K. Spirdowicz, a.g.e., s. 43.

79 E. Simpson, a.g.e., s. 344.

80 E. Simpson, K. Spirdowicz, a.g.e., s. 43, Fig. 15-17, 27, 29, 31.

81 G. Summers, a.g.e., Taf. 1c. 
ğişmez unsurları arasındaki Frig Matar-Kybelesi’nde sıklıkla betimlenen polos, daha önceki çalışmalarda, ince ya da kalın bir dizi disk, abacus ya da kübik silme olarak adlandırılan bezekler aracılığıyla yansıtılmış olmalıdır. Söz konusu bezeğin değişken özellikler sunması, Demir Çağ polos tiplerinde görülen farkl11ıklarla bir arada değerlendirildiğinde şaşırtıcı değildir. Nitekim Kargamış Kubaba'sında kübik formlu bir polos taktığı görülen tanrıça, Boğazköy Kybele'si örneğinde olduğu üzere Frigler tarafından sıklıkla oval, aşağı doğru daralır yapıda polosla betimlenmiştir.

Frig fibulalarında yukarıda sözünü ettiğimiz saptamalar, Tip 7A gibi erken örneklerle birlikte başlamış ve küçük değişimlerle devam etmiştir. Bir süre sonra taşıdığ sembolik anlamı yitirerek tamamen bir modaya dönüşmüş olma ihtimali bulunan ucu kıvrık saç etrafinda şekillenen kompozisyonun Tip7A'yı takip eden süreçte üretilen sırasıyla Tip 13, 3, 2, 4, 5,7, 9, 14, 11 ve 2A alt gruplarında hafif dışa sivriltilmiş bir görüntü ile yansıtılmaya çalışıldığı izlenmektedir. Bunlar arasında yer alan ve İÖ 780-700 yılları arasında aktif kullanım gören Tip 9 fibulalarda söz konusu ucu kıvrık yapının diğerlerinden daha belirgin bir şekilde, pimlere sokulan iğne başı şekilli eklentilerle yuvarlatılmış ve içe dönük şekilde uygulanmış olması dikkat çekmektedir ${ }^{82}$.

Boğazköy Kybele'sinin polosunun, üst üste dörtlü silindir/yuvarlak sıradan oluştuğu ve daha büyük boyutlu ortası friz kuşağı görünümündeki elips bir yükseltiyle sonlandığı bilinmektedir. Bu görüntü de yine Frig fibula süslemelerinde gördüğümüz özelliklerden biri olması itibariyle önemlidir. Anılan heykelin polosu üzerindeki friz kuşă̆ında yer alan dikey süslemeler, özellikle Tip 11 fibulalarda hem iğne tutamak plakası, hem de zemberek kaidesindeki görünüm ile neredeyse birebir benzer niteliktedir. Caner tarafından, MM Tümülüsü fibulaları olarak ele alınan malzemelerde, tıpkı Boğazköy Kybele'sinde olduğu üzere temsili tanrıça görüntüsünün üzerinde yükselen polos görünümlü süslemeler önce bir dizi ince silindir disk, disklerin üzerinde de elips formda daha geniş, orta kısmında kazıma dikine çizgilerden oluşan bezek içermektedir ${ }^{83}$. Bize göre bu uygulama, yukarıda değindiğimiz ucu kıvrık saç uygulaması dışında tanrıça temsilinin fibulalarda sembolik olarak yansıtılmış olabileceğine dair bir başka veridir (G. 5c1-2).

Aslanların, ucu kıvrık saç motifi ile betimlenmiş Matar-Kybele ile olan güçlü bağının resmedildiği Boğazköy dinosu ${ }^{84}$ (G. 3i) sembolizmde yer bulan söz konusu anlatının en net betim özelliklerinden birisini sunması bakımından son derece önemlidir. Nitekim fibulalar üzerinde temsili tanrıça betiminin varlığına dair ele alacağımız son ve önemli uygulamalardan biri, az sayıda Frig tipi fibula örneğinde karşımıza çıkan aslan eklentileridir. Özellikle Doğu Ege merkezlerinden elde edilen örnekler üzerinde görülen bu betimleme, fibulaların çalışmamız içerisinde önerdiğimiz tanrıçanın

82 E. Caner, a.g.e.

83 E. Caner, a.g.e., Taf. 38-492, 496, 499A, Taf. 39-500-506, 508-514.

84 Eva Maria Bossert, Die Keramik Phrygischer Zeit von Boğazköy, Mainz 2000, s. 62-63, cat. no. 272, Farb- 
kutsal hayvanı aslanlarla olan bağlarını temsilden çıkartarak, doğrudan üç boyutlu görünüm halinde sunması bakımından önemlidir. İlk örnek, günümüzde Indiana Üniversitesi Müzesi'nde yer almaktadır ve Prayon tarafından incelenmiştir ${ }^{85}$. İki iğneli mekanizmaya sahip Frig tipi fibulanın ucu kıvrık saç motifini de barındıran tanrıça temsilinin hemen altında yer alan iğne tutamak plakası yüksek tutulmuş, burada diğer Frig tipi fibulalarda pençe olarak tanımladığımız kanca uygulamasının yerine doğrudan minyatür bir aslan heykelciği yerleştirilmiştir (G. 6a). Pençeleri ikili iğne sisteminin kancası olacak şekilde, kavisli ve oyuk düzenlenen aslan heykelciği, Frig düşün dünyasında sembolik üslupla yansıtılan bir durumun ilk gerçekçi görüntüsünü sunması itibariyle son derece önem taşımaktadır.

Tanrıçanın kutsal hayvanı olan aslanın, işlevsel bir şekilde ve heykelcik görüntüsünde oluşturulduğu nadir eserlerin dişında, tamamen bir süsleme aracı olarak Frig tipi fibulalar üzerinde betimlendiği örnekler de bulunmaktadır. Ephesos Artemision buluntuları aracılığıyla tanınan bu tipte fibulanın bir benzerinin, yoğun Frig etkileşimi ile bilinen Niğde Kaynarca'da da görülüyor oluşu ilgi çekicidir ${ }^{86}$. Bammer ve Muss tarafından yayınlanan Ephesos altın Frig tipi fibula örneğinde (G. 6b) iri bir aslan başı, fibulanın merkezinde, yay kısmının hemen üzerinde cepheden işlenmiştir ${ }^{87}$. Fibulanın her iki ayak kısmında yer alan zemberek ve iğne tutamak plakası arasına konumlandırılan aslan başının alt ve üst kısımlarında tanrıça ikonografisinin değişmez unsurlarından dört yapraklı çiçek ve rozet motifinin varlığı dikkat çekmektedir ve bu örnek, fibulaların tanrıça temsili için kullanıldığına dair bizlere bir dayanak sunmaktadır.

\section{Sonuç}

Frigler, Anadolu’ya İÖ 1200 göçleri neticesinde, Balkanlar üzerinden Boğazları aşarak geldiklerine inanılan bir toplumdur. Buna karşın Frig kültür ögeleri bir bütün olarak ele alındığında topluluğun, Anadolu'nun öncül ve çağdaş toplumlarından derin izler taşıdığı bilinmektedir. Alfabesini Fenike'den, başlıca inanç ögesi durumunda bulunan tanrıçasını Geç Hitit coğrafyası ve özellikle Kargamış’tan tanıyarak kendi düşün dünyasında, yeni unsurlar sunarak geliştiren Frigler, maden eser üretiminde de doğulu komşuları Tabal ve Urartu'dan etkilenmişlerdir. Plastik sanat ürünlerini, başta orthostat ve tanrıça kabartmaları olmak üzere yine Geç Hitit biçemleri ile şekillendiren Frigler'in kaya anıtları ve mezarları itibariyle de çağdaşı Urartu'dan izler taşıdığı bilinmektedir. Gerek yazılı kaynaklar, gerekse arkeolojik verilerin doğruladı-

tafel D.

85 F. Prayon, a.g.e., Taf. 31a.

86 Mustafa Akkaya, “Objets Phrygiens en Bronze du Tumulus de Kaynarca”, La Cappadoce Meridionalejusqu 'a la fin de 1'epoque Romaine. Etat des Recherches. Actes du Colloque d'Istanbul 1987, Paris 1992, s. 26-27.

87 Anton Bammer, Ulrike Muss, Das Artemision von Ephesos. Das Weltwunder Ioniens in archaischer und klassischer Zeit, Mainz am Rhein 1996, Abb. 100. 
ğ bu güçlü etkileşim süreci ile birlikte Frigler, “Anadolulu” bir kimlik kazanmakla kalmamış, uzun yıllar boyunca Doğu Ege’yi ancak İÖ 8. yüzyıldan sonra kontrol altına alabilmiş kimi Demir Çağ topluluklarına coğrafyanın köklü kültürel birikimi aktaran ana damarlardan biri olagelmiştir.

Fibulalar, ilk ortaya çıktıkları Geç Tunç Çağ'ından itibaren farklı bölgelerde, farklı tip ve amaçlarla kullanılmış, günümüz çengelli iğnelerinin öncü örnekleridir. Çalışmamızda değindiğimiz üzere, ayrıntılı tipolojisi Blinkenberg tarafından oluşturulmuş olan fibulaların üretildikleri bölgelere göre biçimsel farklılıklar gösterdikleri bilinmektedir. Söz konusu alt gruplar içerisinde değerlendirilen Tip XII, yani Anadolu tipi fibulaların önemli bir bölümünü oluşturan Frig tipi fibulalar, kültürün özgün sanat yapıtları olması açısından son derece önemlidir. Frigler tarafindan üretilmeye başlandıkları İÖ 9. yüzyılın ikinci yarısını takip eden süreçten itibaren, dönem içi ticaret ve etkileşim yoluyla yayılarak Anadolu'nun başta Batısı olmak üzere, pek çok bölgesinde büyük beğeni gören fibulaların zamanla Anadolu sınırlarını aşarak İtalya'ya dek ulaştığı ve bu geniş coğrafyada yerel atölyelerde taklitlerinin üretildikleri bilinmektedir.

Frig tipi fibulalar üzerinde yer alan bezeme şemasında dikkatimizi çeken ve bu çalışmanın ana konusunu oluşturan sembolik tanrıça temsili, Frig sanatının pek çok farklı ögesinde izlenebilir bir durum olması itibariyle ilgi çekicidir. Çalışmamızda değerlendirdiğimiz üzere, heykel, idol, anıt, mühür, ahşap gibi farklı eserler üzerinde varlığı bilinen ve ahşap servis standlarında olduğu gibi temsili sembolizm, tanrıça görüntüsünün üç boyutlu işlendiği sınırlı sayıda esere karşın, daha çok bu şekilde yansıtıldığını göstermesi açısından önem taşımaktadır.

Çalışmamız kapsamında değerlendirdiğimiz fibulalar başta olmak üzere, tanrıçanın değindiğimiz temsili görüntüleri Frigler'in hangi nedenlerle böyle bir yol tercih ettiği konusun sorularını beraberinde getirmektedir. Gerek maden işçiliği, gerekse ahşap ve kaya oyma konusunda yetenekli ustalara sahip olduğu iyi bildiğimiz Frigler'in tanrıçayı betimleme noktasında hangi sebeplerle "sembolizmi" tercih ettiklerini anlamak oldukça güçtür. Buna karşın Frigli ustaların, üzerinde tanrıçanın betimlenmesini planladıkları ögelerin boyutunu göz önüne alarak böylesi bir farklılığa yöneldiklerini düşünmek olasıdır. Nitekim malzeme ve işleniş yöntemlerindeki farklılıklar, servis standları-fibulalar karşılaştırmasında görüldüğü üzere işlenecek alanın daralmasıyla kompozisyonda yer alması mutlak tanrıça ve kutsal hayvanı aslana dair betimlerin bir ölçüde değiştiğini göstermesi açısından önemlidir.

Frig tipi fibulaların özellikle iğne tutamak plakaları, bize göre diğer Frig ögelerinden bildiğimiz tanrıça ikonografisinin önemli, fakat bir o kadar da az değinilen ucu kıvrık saç yapısını, yarı ikonik gövdesi ve aslan pençelerini yansıtmaktadır. Söz konusu plakalarda, herhangi bir işlevsel yönü bulunmayan süsleme ögesi olarak uygu- 
lanan ve öncül çalışmalarda çoğunlukla "boynuz" biçimli olarak değerlendirilen uygulama, tanrıçanın sembolik biçemde temsil edildiği bilinen diğer Frig kültür ögeleri ile karşılaştırıldığında düşüncemiz daha da belirgin hale gelmektedir. İğne tutamak plakalarında andığımız sembolizme dair en yakın yorum Vassileva tarafından dile getirilmiş ve plakaların yapısını aslan pençesine benzetmiştir. Bize göre Vassileva tarafından pençe olarak tanımlanan görünüm, yalnız fibulaların iğne tutamak plakasının uç kısmında yer alan kanca kısmı ile ilgili olmalıdır. Plakanın yivlerle oluşturulan ve çok büyük oranda üçlü bir kanal görünümü yansıtan merkezi tanrıça idolünün gövdesini, her iki yanından kancaya uzanan kanallar ise aslan ayaklarını, aynı servis standlarında olduğu üzere temsil ediyor olmalıdır. Frig tipi fibulaların özellikle Doğu Ege'de üretilen taklitlerinde, minyatür aslan heykelciği ya da cepheden aslan baş1 ile yansitılan bu durumun, doğrudan Frig üretimi fibulalarda gözlemlenmiyor oluşu, tanrıçalarını "Dağlık Frigya"'dan, Ankara ve Kerkenes'e uzanan geniş coğrafyada idol şeklinde betimleyen bir kültür için şaşırtıcı olmasa gerektir.

Fibulalarda tanrıça temsili kadar önemli bir başka konu, söz konusu eser grubunun özellikle İÖ 8-6. yüzyıllarda gözlemlenen kullanım amacına yöneliktir. Bu tarihler arasında Frig coğrafyasında, çoğunlukla tümülüslere bırakılan bir mezar armağanı olan fibulaların, tip ve alt grupları fark etmeksizin Batı'da bambaşka bir amaçla, bu defa tapınak armağanı olarak değerlendirildikleri görülmektedir. Hemen tamamı özünde "anayı" temsil eden Grek Panteonu'nun önemli tanrıçalarına adanan fibulaların, doğrudan doğum ile ilgili konularda tanrıçalara başvuran kadınların tercih ettikleri bir adak armağanı olduğu noktasında bilgilerimizin de bulunuyor olması, söz konusu tanrıça-fibula bağlantıları noktasında ilgi çekicidir ${ }^{88}$.

Tanrıça kültleriyle doğrudan bağlantılı olan fibulaların Frig üretimi örnekleri üzerinde tanrıça sembolizminin hangi amaçla uygulandığı sorusu net bir şekilde cevap bulamasa da, bize göre bu durum "koruyucu tanrıça" düşüncesi ile ilişkili olmalıdır. Etlik Steli üzerinde tanrıçanın gryphon ile olan birlikteliğinin "koruyan ve korunan yön" ile ilişkilendiriliyor oluşu ve gryphonun Yakındoğu örneklerinde ucu kıvrık saç tipini de barındırdığı bilinen kanatlı güneş kursu ile bir arada betimi, ilgi çekici bir özellik olarak yorumlanabilmektedir. Bu noktada, Frig soylularının, koruyucu yönünü ön plana çıkardıkları baş tanrıları "Matar-Kybele"yi hem yaşamları sürecinde, hem de ölümlerinin ardından üzerlerinde taşımak istemiş olmaları olasıdır. Bu doğrultuda, giysilerini tutturmak için kullandıkları fibulalar üzerinde, düşüncelerine paralel olarak, tanrıçanın temsili görüntüsünü yansıtmış oldukları düşünülebilir. Simpson'un ahşap servis standları için sunduğu "taşınabilir kült anıtı" önermesiyle paralel olarak tanrıça temsilinin işlendiği fibulaların, işlevsel yönlerinden çok, Frig soyluları için tasarlanmış "taşınabilir kült objesi” oldukları düşünülmektedir.

88 Ayrıntılı bilgi için bkz. Emre Erdan, “Aydın Arkeoloji Müzesi’nden Bir Grup Frig Tipi Fibula”, Arkeoloji ve Sanat, C. 156, İstanbul 2017, s. 51 vd. 


\section{Görseller}

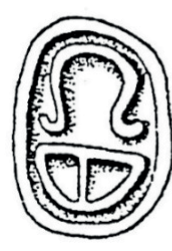

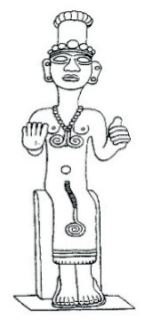

b

G. 1. a. Acemhöyük Mührü. (Boehmer, Güterbock 1987: Abb. 27h); b. Ninhursag Heykelciği Çizim. (Motz 1992: Fig. 32).

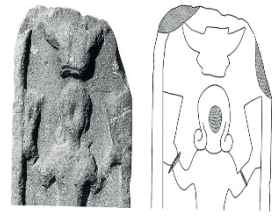

a

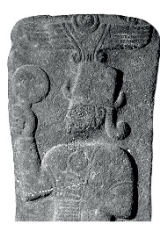

d

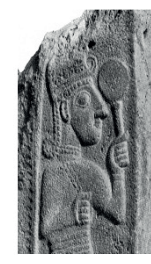

b

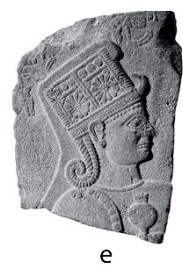

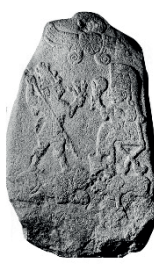

c

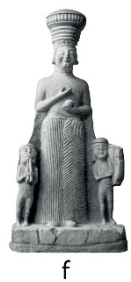

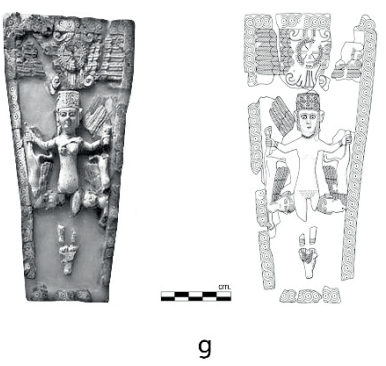

G. 2. a. Meharde Steli Detay. (Hawkins 2000: Pl. 225-226); b. Zincirli Kubabas1. (van Loon 1991: Pl. XV); c. Melid Kubabas1. (Orthmann 1971: Taf. 42f); d. Birecik Kubabas1. (Orthmann 1971: Taf. 5c); e. Kargamış Kubabası (Orthmann 1971: Taf. 23b); f. Boğazköy Kybelesi. (Prayon 1987: Taf. 3); g. Gordion Fildişi At Koşum Parçası. (Prayon 1987: Taf. 44c). 


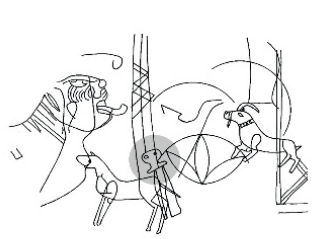

a

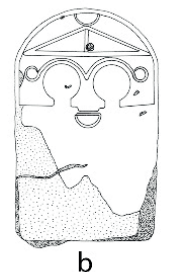

b
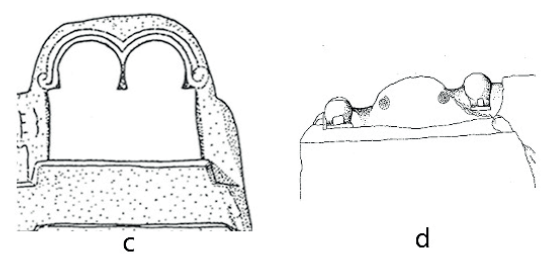
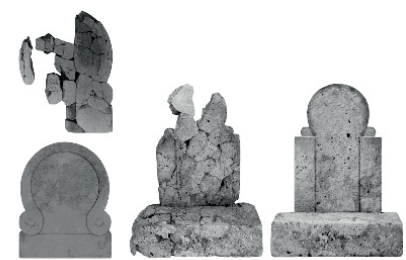

e

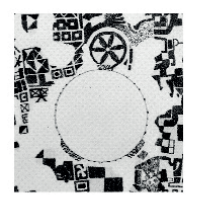

$\mathrm{h}$

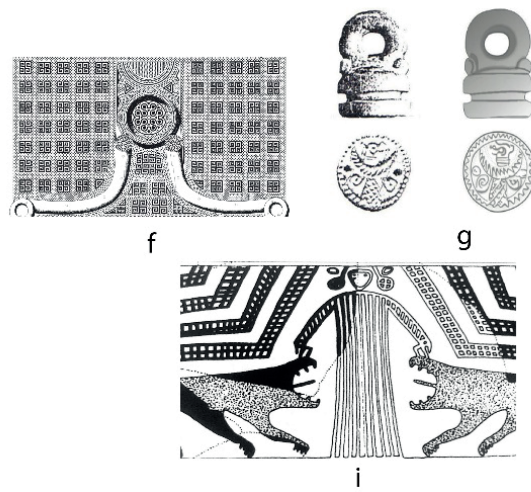

G. 3. a. Gordion Megaron 2 Çizim, İdol. (Roller 2009: 56-58); b. Sincan Steli. (Metin, Akalın 2001: Pl. 5); c. Kitabeli Sunak. (Tüfekçi Sivas 1999: Lev. 125-126); d. Köhnüş 2 No'lu Anıt. (Tüfekçi Sivas 1999: Lev. 147-150); e. Kerkenes İdolleri. (Summers 2006: Taf. 1a-c); f. MM

Tümülüsü Servis Stand1. (Simpson, Spirdowicz 1999: Fig. 31); g. Frig Mührü. (Dusinberre 2005: Fig. 31); h. Gordion Megaron 2'ye ait Mozaik Taban. (Young 1965: 11); i. Boğazköy Frig dinosu üzerinde betimlenen tanrıça ve aslanlar. (Bossert 2000, 62-63, cat. no. 272, Farbtafel D) 


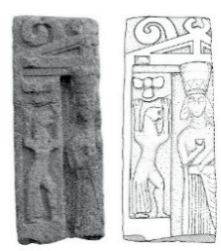

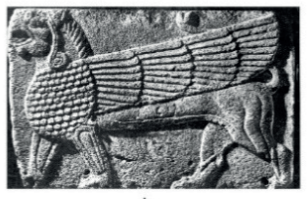

b

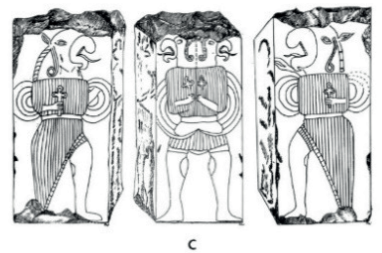

G. 4. a. Etlik Steli. (Prayon 1987: Taf. 9b); b. Ankara Frig Ortostatı. (Prayon 1987: Taf. 7b); c. Daydalı Gryphonları. (Uçankuş 1971, Lev. X)
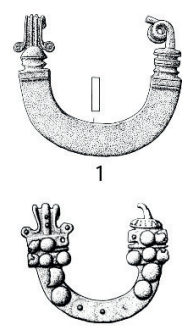

3
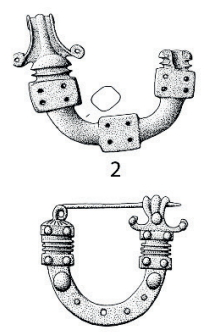

4

a

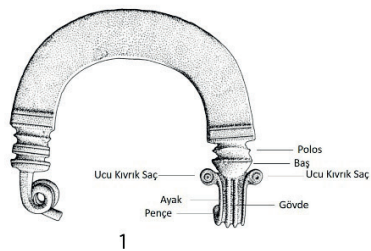

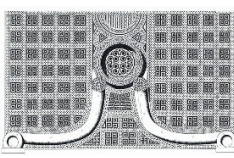

2

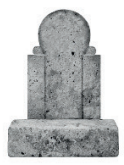

3

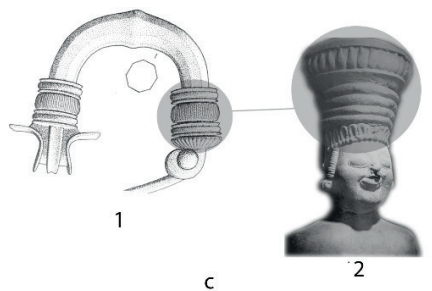

G. 5. a1. Simav'dan Frig Tipi Fibula. (Caner 1983: Taf. 16-211); a2. Uşak’tan Frig Tipi Fibula. (Caner 1983: Taf. 37-483); a3. Eskişehir'den Frig Tipi Fibula. (Caner 1983: Taf. 29361A); a4. Frig Tip 9 Fibula. (Caner 1983: Taf. 34-434); b1. Simav'dan Frig Tipi Fibula. (Caner 1983: Taf. 16-211); b2. MM Tümülüsü Servis Standı. (Simpson, Spirdowicz 1999: Fig. 31); b3. Kerkenes İdolü. (Summers 2006: Taf. 1); c1. MM Tümülüsü’nden Fibula Örneği. (Caner 1983:

Taf. 38-492); c2. Boğazköy Kybele Polos Detayı. (Prayon 1987: Taf. 3c) 


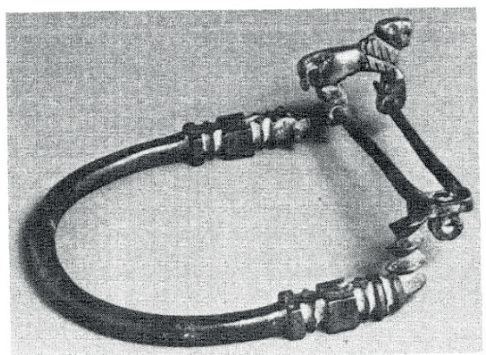

a

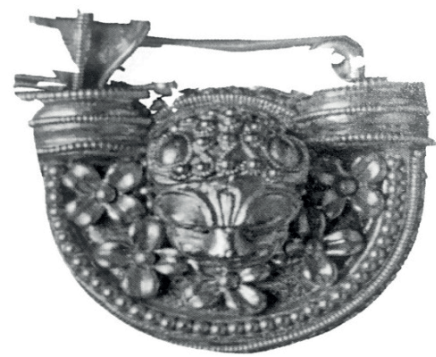

b

G. 6. a. Indiana Üniversitesi Müzesi’nden Frig Tipi Fibula. (Prayon 1987: Taf. 31a); b. Ephesos Artemision'da Ele Geçen Frig Tipi Fibula. (Bammer, Muss 1996, Abb. 100) 


\section{Kaynakça/References}

AKKAYA, Mustafa, "Objets phrygiens en Bronze du tumulus de Kaynarca”, La Cappadoce Meridionalejusqu 'a la fin de 1'epoque Romaine. Etat des Recherches. Actes du Colloque d'Istanbul 1987, Paris 1992. s. 25-27.

AKURGAL, Ekrem, Phrygische Kunst, Ankara 1955.

ALP, Sedat, Konya Civarında Karahöyük Kazılarında Bulunan Silindir ve Damga Mühürleri, Ankara 1994.

BAMMER, Anton; MUSS, Ulrike, Das Artemision von Ephesos. Das Weltwunder Ioniens in Archaischer und klassischer Zeit, Mainz am Rhein 1996.

BERNDT ERSÖZ, Susanne, "Cutting The Gordian Knot: The Iconography of Megaron 2 at Gordion”, Opuscula-Annual of The Swedish Institutes at Athens and Rome, C. 8, Rome 2015, s. $99-122$.

BİLGEN, Nejat, “Frigya' da Ninhursag İnancının İpuçları”, Anadolu Üniversitesi I. Uluslararası Dünden Bugüne Eskişehir Sempozyumu: Siyasal, Ekonomik, Sosyal ve Kültürel Yapı, Eskişehir 2005, s. 357-361.

BİLGİ, Önder, Anadolu’da İnsan Görüntüleri: Klasik Çağ Öncesi, İstanbul 2012.

BITTEL, Kurt, "Untersuchungen auf Büyükkale. Das Archiv im Gebäude K. Das Phrygische Burgtor in vx/ 6-7", MDOG, C. 91, 1958, s. 57-72.

BLACK, Jeremy; GREEN, Anthony, Gods, Demons and Symbols of Ancient Mesopotamia: An Illustrated Dictionary, London 1992.

BLINKENBERG, Christian Sørensen, Fibules Grecques et Orientales, Kobenhavn 1926.

BOEHMER, Rainer Michael, Die Kleinfunde aus der Unterstadt von Boğazköy: Grabungskampagnen 1970-1978, Berlin 1972.

BOEHMER, Rainer Michael; GÜTERBOCK, Hans Gustav, Glyptik aus dem Stadtgebiet von Boğazköy: Grabungskampagnen 1931-1939, 1952-1978, Berlin 1987.

BOSSERT, Eva Maria, Die Keramik Phrygischer Zeit von Boğazköy: Funde aus den Grabungskampagnen 1906, 1907, 1911, 1912, 1931-1939 Und 1952-1960, Mainz 2000.

BRYCE, Trevor, The World of the Neo-Hittite Kingdoms: A Political and Military History, Oxford 2012.

BUDIN, Stephanie Lynn, Images of Woman and Child From The Bronze Age: Reconsidering Fertility, Maternity, and Gender in The Ancient World, Cambridge 2011.

CANER, Ertuğrul, Fibeln in Anatolien: Prähistorische Bronzefunde. Abteilung XIV, München 1983.

DÖNMEZ, Sevgi, "Eski Yakındoğu'da Yılanlı Tanrıça Kültü Üzerine Bir Değerlendirme”, Tarih İncelemeleri Dergisi, C. XXXII/2, 2017, s. 407-426.

DUSINBERRE, Elspeth, Gordion Seals and Sealings Individuals and Society, Pennsylvannia 2005.

ENSERT, Hatice Kübra, “M. Ö. İkinci Binde "Kanatlı Güneş Kursu” İle Taçlandırılmış Anadolulu Hitit Figürleri”, Anadolu/Anatolia, C. 28, 2005, s. 25-47.

ERDAN, Emre, “Aydın Arkeoloji Müzesi’nden Bir Grup Frig Tipi Fibula”, Arkeoloji ve Sanat, C. 156, İstanbul 2017, s. 51-60.

FRANKFORT, Henri, “A Note on the Lady of Birth”, Journal of Near Eastern Studies, C. 3(3), 1944, s. 198-200. 
FUHR, Ilse, Ein altorientalisches Symbol: Bemerkungen zum sogenannten "omegaförmigen Symbol" und zur Brillenspirale, Wiesbaden 1967.

HAWKINS, John David, Corpus of Hieroglyphic Luwian Inscriptions. Volume I, Inscriptions of the Iron Age, Berlin 2000.

HAWKINS, John David, "Cilicia, the Amuq, and Aleppo", Near Eastern Archaeology, C. 72, 2009, s. 164-173.

HINKE, William John, A New Boundary Stone of Nebuchadrezzar I From Nippur, Philadelphia 1907.

JORDAN, Michael, Dictionary of Gods and Goddesses, New York 2004.

KING, Leonard William, Babylonian Boundary-stones and Memorial-tablets in The British Museum, London 1912.

LEICK, Gwendolyn, A Dictionary of Ancient Near Eastern Mythology, London 1991.

MARGREITER, Ingrid, Alt-Ägina II. 3-Die Kleinfunde aus dem Apollon-Heiligtum, Darmstadt 1988.

MELLINK, Machteld Johanna, A Hittite Cemetery at Gordion, Philadelphia 1956.

METIN, Mustafa; AKALIN, Mehmet, “Frigyada Bulunan İkiz İdol”, Anadolu Medeniyetleri Müzesi 2000 Yıllığı, 2001, s. 183-188.

MORI, Masao; OMURA, Sachihiro, "1988 Kaman-Kalehöyük Kazıları”, KST, C. 11, 1990, s. $335-355$

MOTZ, Lotte, The Faces of Goddess, New York 1997.

MUSCARELLA, Oscar White, Phrygian Fibulae From Gordion (No. 4), London 1967a.

MUSCARELLA, Oscar White, "Fibulae Represented on Sculpture", Journal of Near Eastern Studies, C. 26 (2), 1967b, s. 82-86.

MUSCARELLA, Oscar White, "Frig Fibulaları/Phrygian Fibulae”, Friglerin Gizemli Uygarlığı / The Mysterious Civilization of the Phrygians, Ed. T. Tüfekçi Sivas, H. Sivas, İstanbul 2007, s. 173-181.

NEVE, Peter, Hattuša-Stadt der Götter und Tempel: Neue Ausgrabungen in der Hauptstadt der Hethiter, Darmstadt 1992.

ORLIN, Eric, Routledge Encyclopedia of Ancient Mediterranean Religions, Abington 2015.

ORTHMANN, Winfried, Untersuchungen zur Späthethitischen Kunst, Bonn 1971.

VON DER OSTEN, Hans Henning, The Alişar Hüyük Seasons of 1930-1932 Part II, Chicago 1933.

ÖZGÜÇ, Nimet, "Samsat Mühürleri”, Belleten, C. 51, 1987, s. 429-439.

PRAYON, Friedhelm, Phrygische Plastik: Die früheisenzeitliche Bildkunst Zentral-Anatoliens und ihre Beziehungen zu Griechenland und zum Alten Orient, Tübingen 1987.

ROLLER, Lynn, The Incised Drawings from Early Phrygian Gordion, Philadelphia 2009.

SEIDL, Ursula, Die Babylonischen Kudurru-Reliefs: Symbole Mesopotamischer Gottheiten, Freiburg 1989.

SEVIN, Veli, "Frigler", Anadolu Uygarlıkları Ansiklopedisi, C. 2, 1982, s. 248-274.

SIMPSON, Elizabeth, "Gordion Mobilya ve Ahșap Eserleri”, Frigler, Midas'ın Ülkesinde, Anıtların Gölgesinde/ In the Land of Midas, In the Shadow of Monuments, Ed. T. Tüfekçi Sivas, H. Sivas, İstanbul 2012, s. 334-360. 
SIMPSON, Elizabeth; SPIRDOWICZ, Krysia, Gordion Wooden Furniture: The Study, Conservation and Reconstruction of the Furniture and Wooden Objects from Gordion, 19811998, Ankara 1999.

SUMMERS, Geoffrey, "Phrygian Expansion to The East: Evidence of Cult from Kerkenes Dağ", BaM, C. 37, 2006, s. 647-658.

SUMMERS, Geoffrey; SUMMERS, Françoise, "Kerkenes Dă̆”, Frigler, Midas'ın Ülkesinde, Anıtların Gölgesinde/ In the Land of Midas, In the Shadow of Monuments, Ed. T. Tüfekçi Sivas, H. Sivas, İstanbul 2012, s. 162-181.

TÜFEKÇİ SIVAS, Taciser, Eskişehir-Afyonkarahisar-Kütahya İl Sınırları İçindeki Phryg Kaya Anıtları, Eskişehir 1999.

UÇANKUŞ, Hasan Tahsin, “Emirdağı'nda Yeni Bulunan Bir Hitit Kabartması”, Belleten, C. 35/139, 1971, s. 359-378.

VAN LOON, Maurits Nanning, Anatolia in the Earlier First Millennium B.C. Iconography of Religions, Leiden 1991.

VASSILEVA, Maya, “Phrygian Rock-Cut Thrones, 'Idols' and Phrygian Royal Symbolism”, Thracia, 18, 2009, s. 111-124.

VASSILEVA, Maya, "Frig Tunç İşlemeciliği”, Frigler, Midas'ın Ülkesinde, Anıtların Gölgesinde/ In the Land of Midas, In the Shadow of Monuments, Ed. T. Tüfekçi Sivas, H. Sivas, İstanbul 2012, s. 310-334.

VASSILEVA, Maya, "Early Bronze Fibulae and Belts from the Gordion Citadel Mound", The Archaeology of Phrygian Gordion, Royal City of Midas: Gordion Special Studies 7, Ed. C. B. Rose, Pennsylvania 2013, s. 111-126.

YOUNG, Rodney Stuart, "Early Mosaics at Gordion”, Expedition, C. 7/3, 1965, s. 4-13.

ZIMMERN, Heinrich, Die Göttersymbole des Nazimaruttaš-Kudurru, Leipzig 1906. 
